\title{
Autologous platelet-rich plasma action on skin autografts in horses
}

\author{
Ana Carolina Barros da Rosa Pedroso ${ }^{* *}$ (D) Ana Kellen Lima de Queiroz ${ }^{2}$ (D) \\ Eric Saymon Andrade de Brito $^{3}$ (D) Joel Phillipe Costa e Souza ${ }^{2}$ (D) Marina Pacheco Miguel ${ }^{4}$ (D) \\ Luciana Ramos Gaston Brandstetter ${ }^{5}$ (D) Veridiana Maria Brianezi Dignani de Moura $^{3}$ (D)
}

1Programa de Pós-graduação em Ciência Animal, Escola de Veterinária e Zootecnia (EVZ), Universidade Federal de Goiás (UFG), 74690900,
Goiânia, GO, Brasil. E-mail: anacarolinapedroso@ymail.com. *Corresponding author.
${ }^{2}$ Curso de Medicina Veterinária, Escola de Veterinária e Zootecnia (EVZ), Universidade Federal de Goiás (UFG), Goiânia, GO, Brasil.
${ }^{3}$ Setor de Patologia Animal, Escola de Veterinária e Zootecnia (EVZ), Universidade Federal de Goiás (UFG), Goiânia, GO, Brasil.
${ }^{4}$ Instituto de Patologia Animal e Saúde Pública, Universidade Federal de Goiás (UFG), Goiânia, GO, Brasil.
${ }^{5}$ Departamento de Medicina Veterinária, Escola de Veterinária e Zootecnia (EVZ), Universidade Federal de Goiás (UFG), Goiânia, GO, Brasil.

ABSTRACT: This study evaluated the action of autologous platelet-rich plasma (PRP) on cutaneous wounds, containing skin autografts, in the gluteal region of horses. Seven healthy horses were used. Two $6 \times 6 \mathrm{~cm}$ cutaneous wounds were produced on each side of the gluteal region. Eight days after wound induction, grafts were performed with skin fragments harvested from the neck, as well as the application of PRP, prepared by double-centrifugation protocol. Wounds with autografts on the left side received PRP (group T), and those with autografts on the right side did not receive treatment (group C). Macroscopic and microscopic evaluations were performed, considering the integration of autografts and retraction of wound edges, as well as neovascularization, inflammatory infiltrate, young fibroblasts, collagenization, reepithelization and autografts integration. There was no difference between the groups $(P>0.05)$ in relation to most macroscopic and microscopic variables. However, neovascularization was significantly greater $(p=0.0191)$ in group $T$, on the $14^{\text {th }}$ day after grafting. It is concluded that PRP favors the process of skin repair with autografts in horses, since it increases the neovascularization in the initial phase of wound healing. Furthermore, the PRP seems to positively influence the integration of the skin autografts and the retraction of the wound edges. Key words: granulation tissue, retraction of the wound edges, skin grafts, wound healing.

Ação do plasma rico em plaquetas autólogo em autoenxertos de pele em equinos

RESUMO: Este estudo avaliou a ação do plasma rico em plaquetas (PRP) autólogo em feridas cutâneas, contendo autoenxertos de pele em equinos. Foram utilizados sete equinos hígidos, nos quais foram produzidas duas feridas cutâneas de $6 x 6 \mathrm{~cm}$, em cada um dos lados da região glútea. Oito dias após a indução das feridas, foram realizados enxertos com fragmentos de pele colhidos do pescoço, assim como a aplicação do PRP, preparado através de protocolo de dupla centrifugação. As feridas com autoenxertos do lado esquerdo receberam PRP (grupo T), $e$ as com autoenxertos do lado direito não receberam tratamento (grupo C). Foram realizadas avaliações macroscópica e microscópica, considerando as variáveis integração dos autoenxertos e retração das bordas da ferida, além de neovascularização, infiltrado inflamatório, fibroblastos jovens, colagenização, reepitelização e integração dos autoenxertos. Não houve diferença entre os grupos ( $p>0,05)$ em relação à maioria das variáveis macroscópicas e microscópicas. Contudo, a neovascularização foi significativamente maior $(P=0,0191)$ no grupo T, no $14^{\circ}$ dia após a realização da enxertia. Conclui-se que o PRP favorece o processo de reparo da pele com autoenxertos em equinos, já que aumenta a neovascularização na fase inicial da cicatrização da ferida. Ainda, o PRP parece influenciar positivamente a integração dos autoenxertos de pele e a retração das bordas da ferida.

Palavras-chave: enxerto de pele, cicatrização, tecido de granulação, retração das bordas da ferida.

\section{INTRODUCTION}

The frequency of cutaneous injuries in horses is very high and leads to expensive treatments. This species shows slow and difficult healing, especially in wounds located in distal limbs. This can be attributed to several factors (WILMINK et al., 1999; THEORET et al., 2001; SCHWARTZ et al., 2005; COCHRANE et al., 2017; LEPAULT et al., 2017), which leads to the development of chronic wounds (BERTONE, 1989) and, consequently, to damages to animal health.

The use of skin grafts should be considered in extensive wounds with great tissue loss and insufficient skin for adequate closure and in sites of difficult healing, such as distal limbs in horses (SCHUMACHER \& 
WILMINK, 2017). Their use can improve the healing result (BRISTOL, 2005) as they reduce the granulation surface and stimulate wound contraction, thus accelerating healing (DAHLGREN, 2009).

Platelet-rich plasma (PRP) is a fraction of autologous blood plasma, with a higher platelet concentration than in whole blood (MARX, 2001). It is an autogenous product with a low risk of transmission of infectious diseases (PIERCE et al., 1991) and great potential for the integration of various types of grafts (VENDRAMIN et al., 2009). PRP represents a mixture of growth factors and other proteins that have synergistic biological effects and act as mediators in the healing process (BADYLAK, 2004). The growth factors are associated with the stimulation to inflammatory response, angiogenesis, fibroblast proliferationand, consequently, increased collagen synthesis (MARX, 2004).

Therefore, this study verified the action of autologous PRP on cutaneous wounds containing autografts in the gluteal region of horses through macroscopic and microscopic evaluations.

\section{MATERIALS AND METHODS}

Seven crossbreed horses (five males and three females), aged from 3-18 years and mean live weight of $350 \mathrm{~kg}$, were used. Prior to the beginning of the experimental period, the animals were submitted to clinical and hematological examinations to ensure their health conditions.

\section{Wound induction}

Horses were sedated with $1 \%$ detomidine hydrochloride at a dose of $20-40 \mu \mathrm{g} / \mathrm{kg}$. Local inverted $U$-anesthesia was performed with $2 \%$ lidocaine hydrochloride. Two $6 \times 6 \mathrm{~cm}$ wounds were performed, one on each side of the gluteal region, covering the entire thickness of the skin and subcutaneous tissue. In order to promote analgesia, the animals received two doses of $25 \mathrm{mg} / \mathrm{kg}$ sodium dipyrone intravenously, one at the end of the surgical procedure and the other after 12 hours. Daily dressings were performed. On the eighth day after wound induction, at which time the granulation tissue filled the defect created up to the adjacent skin level, PRP was prepared, skin fragments were collected for autograft, grafting procedure was carried out, and PRP was applied.

\section{PRP obtaining}

A few hours before the autografts were applied, PRP was prepared. To this end, $20 \mathrm{ml}$ of blood were collected from each animal by jugular puncture with the aid of a $21 \mathrm{G}$ needle and vacuum tubes with $3.2 \%$ sodium citrate. To obtain PRP, a protocol adapted from CARMONA (2006) was used, with double centrifugation, the first one for $1 \mathrm{~min}$ at $900 \mathrm{rpm}$ and the second for $5 \mathrm{~min}$ at $1800 \mathrm{rpm}$. PRP was used immediately after its preparation.

\section{Collection of skin fragments for graft, preparation of the receptor site, and grafting procedure}

Horses were sedated according to the protocol used for wound induction. The neck region under the mane was submitted to trichotomy, antisepsis, and local anesthesia, also according to the protocol previously used. With the aid of a $6 \mathrm{~mm}$ diameter biopsy punch, 12 fragments of skin of the neck were collected with $1 \mathrm{~cm}$ from each other, being the subcutaneous fascia and fat removed with the aid of curved Mayo scissors. Receptor wounds in the gluteal region were washed with sterile saline solution to remove any impurities. A biopsy punch of $4 \mathrm{~mm}$ in diameter was used to create six defects on the granulation tissue of each of the two wounds, left and right, producing receptor beds for autografts. Six fragments of skin extracted from the neck were submerged in PRP previously prepared and implanted in the defects created in the wound of the left gluteal region of each animal, being considered the treated group (group T). The rest of PRP was applied topically on the wounds at the end of the insertion of fragments. The wound on the right side of each animal received the other six grafts, but without PRP application, composing the control group (group C). Then, in both wounds, a dressing with non-adherent Rayon bandage, gauze, and tape was performed. Daily dressings were performed and the wounds were kept closed until complete healing.

\section{Macroscopic evaluation}

Macroscopically, the integration of autografts was evaluated on the days 14 and 28 after the grafting procedure, considering the amount of skin fragments that remained at the implant site. Thus, values of $100 \%, 83 \%, 66 \%, 50 \%, 33 \%$, and $16 \%$ were considered for the integration of six, five, four, three, two, and one autografts, respectively. The retraction of wound edges was evaluated by morphometry from digital photographs obtained weekly until the 35 th day after the grafting procedure, making seven moments of evaluation. A caliper was used as a reference for the computerized evaluation, which was performed with the Image ${ }^{\circledR}$ program, 
through which the area of wound granulation was obtained at the seven evaluation moments.

\section{Microscopic evaluation}

Wound biopsies were performed with the aid of a number 15 scalpel blade at 14,28 , and 35 days after insertion of autografts of both wounds, contemplating a portion of the grafted fragment and a portion of the granulation tissue. The fragments were fixed in $10 \%$ buffered formalin for 48 hours, processed, paraffin embedded, and stained with hematoxylin and eosin (HE) and picrosirius. Histological sections stained with HE were observed under an optical microscope and evaluations were performed considering the variables intensity of neovascularization, inflammatory infiltrate, young fibroblasts, and collagenization, for which, when present, the scores discrete (1), moderate (2), and accentuated (3) were assigned. The integration of autograft was also evaluated, considered present when was observed tissue continuity between the granulation tissue of the recipient bed and the dermis of the implanted fragment. In addition, reepithelialization was considered complete when there was continuity between the epithelium of the implanted fragment and that of the wound edges or incomplete when there was a discontinuity. The histological sections stained with picrosirius were evaluated in relation to the amount of collagen fibers. For this evaluation, five-field photomicrographs of each slide were submitted to analysis by the Image $\mathrm{J}^{\circledR}$ program, by which the mean percentage of collagen fibers present in relation to the total area of each field was obtained.

\section{Statistical analysis}

The statistical analysis of the evaluated parameters was initially performed quantitatively by calculating the mean and standard deviation for the parametric variables and the median for the nonparametric variables. Subsequently, the parametric variables were submitted to analysis of variance (ANOVA) and Tukey's test. From them, those that did not present normality by the Shapiro-Wilk test were then submitted to the non-parametric Kruskal-Wallis test. Statistical differences were considered when the probability value was lower than $0.05(\mathrm{P}<0.05)$ in the ANOVA table. Nonparametric variables were analyzed by the Wilcoxon test (T-test) for paired data. The statistical program $\mathrm{R}$ was used for the data analysis (Version 3.3.1 - 2016 - The R Foundation for Statistical Computing).

\section{RESULTS}

The protocol used to prepare PRP resulted, on average, in a platelet count 3.2 times higher than that of the whole blood of each animal. A higher percentage of integration of autografts was observed in group $\mathrm{T}$ at the two moments of evaluation; although, no statistical difference was observed $(\mathrm{P}<0.05)$. The means and standard deviations for the morphometric evaluation of wounds are shown in table 1. No significant difference was observed between groups $\mathrm{T}$ and $\mathrm{C}(\mathrm{P}>0.05)$. In spite of this, at six moments, wounds of group $\mathrm{T}$ presented a smaller area when compared to those of group $\mathrm{C}$ (Figure 1). In addition, the treated side in six animals showed a complete wound closure, on average, five days before the last evaluation (35th day), while on the untreated side, four animals did not present a complete wound closure at 35 days.

The medians of the microscopic variables are shown in table 2 . No significant difference $(\mathrm{P}>0.05)$ was observed between groups $\mathrm{T}$ and $\mathrm{C}$ in relation to the amount of inflammatory infiltrate, young fibroblasts, collagenization, and integration of autografts. Neovascularization on the 14th day after grafting was significantly higher in group $\mathrm{T}(\mathrm{P}=0.0191)$, which was not observed at the other moments (Figure 2). No difference was observed in relation to re-epithelialization when groups $\mathrm{C}$ and $\mathrm{T}$ were compared $(\mathrm{P}>0.05)$. Collagen quantification, obtained through picrosirius staining, also did not show statistical differences when comparing the groups $\mathrm{T}$ and $\mathrm{C}(\mathrm{P}>0.05)$.

Table 1 - Means and standard deviations of the morphometric evaluation of wounds represented in the area $\left(\mathrm{cm}^{2}\right)$ at the seven moments of evaluation.

\begin{tabular}{ccc}
\hline & Group (T) & Group (C) \\
\hline T1 & $34.69 \pm 1.09^{\mathrm{a}}$ & $36.36 \pm 3.06^{\mathrm{a}}$ \\
T2 & $30.83 \pm 2.50^{\mathrm{a}}$ & $30.91 \pm 2.09^{\mathrm{a}}$ \\
T3 & $16.2 \pm 4.05^{\mathrm{a}}$ & $15.5 \pm 5.31^{\mathrm{a}}$ \\
T4 & $7.13 \pm 2.69^{\mathrm{a}}$ & $7.94 \pm 4.33^{\mathrm{a}}$ \\
T5 & $2.37 \pm 1.41^{\mathrm{a}}$ & $4.57 \pm 3.74^{\mathrm{a}}$ \\
T6 & $0.48 \pm 0.53^{\mathrm{a}}$ & $1.85 \pm 2.41^{\mathrm{a}}$ \\
T7 & $0.16 \pm 0.31^{\mathrm{a}}$ & $0.79 \pm 1.35^{\mathrm{a}}$ \\
\hline
\end{tabular}

Values followed by different letters in the same row and variable differ from each other by the Tukey's test $(\mathrm{P}<0.05)$. 


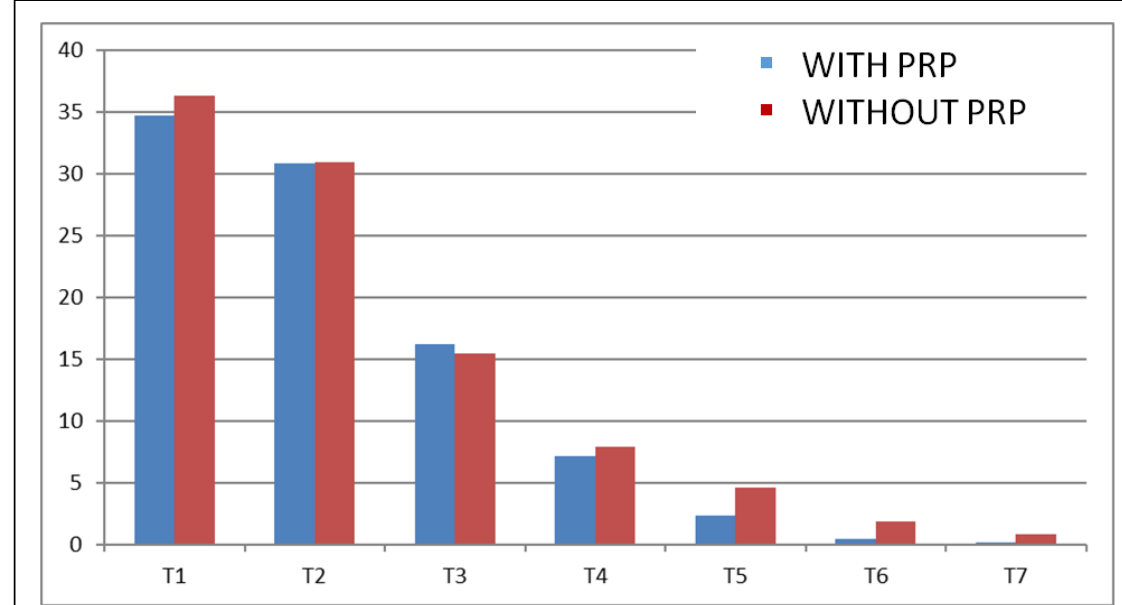

Figure 1 - Graphical representation of the means and standard deviations of the morphometric evaluation of wounds represented in the area $\left(\mathrm{cm}^{2}\right)$ at the seven moments of evaluation, at groups with and without platelet-rich plasma (PRP).

\section{DISCUSSION}

The protocol used to prepare PRP concentrated platelets, on average, 3.2 times the concentration of the whole blood. Despite the controversies on the ideal platelet concentration, it is known that there is a range of efficacy and that low or very high concentrations may be ineffective or result in adverse effects (LANSDOWN \& FORTIER, 2017). Studies have shown that counts of one to four times above the baseline result in positive effects on tissue regeneration (HEE et al., 2003; SANCHEZ et

Table 2 - Median of the variables neovascularization, inflammatory infiltrate, young fibroblasts, collagenization, and integration of autografts in histological sections of skin wounds of horses treated or not with PRP at 14, 28, and 35 days after the grafting procedure.

\begin{tabular}{|c|c|c|c|c|}
\hline Variables & TIME & Group (T) & Group (C) & $P$ value \\
\hline \multirow{3}{*}{ Neovascularization } & D14 & $3^{\mathrm{a}}$ & $2^{\mathrm{b}}$ & 0.0431 \\
\hline & D28 & $2^{\mathrm{a}}$ & $2^{\mathrm{a}}$ & 0.0593 \\
\hline & D35 & $1^{\mathrm{a}}$ & $1^{\mathrm{a}}$ & 0.1088 \\
\hline \multirow{3}{*}{ Inflammatory inflitrate } & D14 & $1^{\mathrm{a}}$ & $2^{\mathrm{a}}$ & 0.1775 \\
\hline & D28 & $1^{\mathrm{a}}$ & $1^{\mathrm{a}}$ & 0.1088 \\
\hline & D35 & $1^{\mathrm{a}}$ & $1^{\mathrm{a}}$ & 0.7150 \\
\hline \multirow{3}{*}{ Young fibrobasts } & D14 & $3^{\mathrm{a}}$ & $3^{\mathrm{a}}$ & 0.1797 \\
\hline & D28 & $2^{\mathrm{a}}$ & $3^{\mathrm{a}}$ & 0.4227 \\
\hline & D35 & $2^{\mathrm{a}}$ & $1^{\mathrm{a}}$ & 0.7150 \\
\hline \multirow{3}{*}{ Collagenization } & D14 & $1^{\mathrm{a}}$ & $1^{\mathrm{a}}$ & 0.1797 \\
\hline & D28 & $2^{\mathrm{a}}$ & $2^{\mathrm{a}}$ & 0.4227 \\
\hline & D35 & $1^{\mathrm{a}}$ & $1^{\mathrm{a}}$ & 0.0679 \\
\hline \multirow{3}{*}{ Integration of autografts } & D14 & $1 \mathrm{a}$ & $1^{\mathrm{a}}$ & 0.5930 \\
\hline & D28 & $2^{\mathrm{a}}$ & $2^{\mathrm{a}}$ & 0.6547 \\
\hline & D35 & $1^{\mathrm{a}}$ & $2^{\mathrm{a}}$ & 0.1056 \\
\hline
\end{tabular}

Scores: absent (0), discrete (1), moderate (2), accentuated (3). Values followed by different letters in the same row and variable differ from each other by the Wilcoxon test $(\mathrm{p}<0.05)$. 


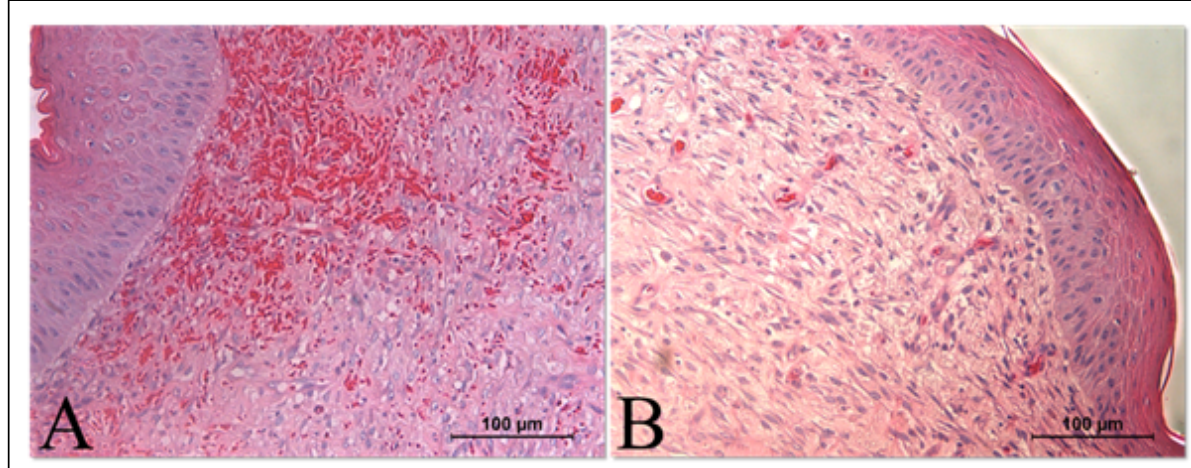

Figure 2 - Photomicrographs of the equine skin wound on the 14th day after the grafting procedure. A) Accentuated neovascularization (score 3 ) in the cutaneous wound of the animal of group T. B) Discrete neovascularization (score 1) observed in equine skin wound of group C. HE, 200x magnification.

al., 2007). Another study establishes that the adequate platelet concentration should be greater than six times the initial concentration for positive outcomes at wound healing (VENDRAMIN et al., 2009). Therefore, the mean platelet concentration obtained in this study can be considered adequate or slightly below that recommended by some authors.

The macroscopic evaluation showed no difference between groups regarding the integration of autografts. However, it seems clear to us the positive effect of PRP on the fixation of grafted skin fragments since all the animals in the treated group presented $100 \%$ integration of implanted fragments, which did not occur in the control group. Thus, it is suggested that the reduced number of evaluated animals justifies the absence of difference between treated and control groups. Another study (VENDRAMIN et al., 2010) reported a better integration of grafts when PRP was used in chronic wounds grafted with skin fragments in human. Similarly, the use of PRP gel was evaluated associated with skin grafts in the treatment of chronic ulcers in diabetic patients and significantly better results regarding integration in the treated group were reported (TZENG et al., 2013). Moreover, another study (BONFÁ et al., 2017) reported a lower loss of grafts when evaluating the effect of PRP gel on the healing of cutaneous grafts of horses. Results of these studies, together with the fact that all the animals treated in this study showed $100 \%$ integration of autografts, reinforce the idea of the beneficial effect of platelets in the healing process of cutaneous wounds treated with autografts and PRP.

The macroscopic result on the integration of skin fragments in GT was not observed in the microscopic evaluation of this same variable, which can be explained by the mechanical aggression caused at the time of sample collection. The binding between the receptor bed and the implanted fragment is initially due to the adhesion of fibrin in the wound and; subsequently, to neovascularization, fibroblastic proliferation, and collagenization. Although, the graft can be considered firmly adhered after the tenth day (SCHUMACHER \& WILMINK, 2017), the mechanical aggression caused by the scalpel blade and forceps at the biopsy time may have contributed to the rupture of this adhesion.

The morphometric evaluation, in which the epithelial covered area was considered macroscopically, did not show a significant difference between groups; although, most of the wounds in the group treated with PRP presented a higher epithelization. In addition, the time of complete closure of wounds was lower in six animals of the treated group. In this context, a study (VENDRAMIN et al., 2010) also reported a better evolution of grafts when using PRP in chronic wounds in humans. Moreover, another study (TZENG et al., 2013) corroboratesthese findings, considering that the authors reported a shorter time in the complete healing of cutaneous ulcers treated with skin grafts and PRP in diabetic patients.

Results of the group treated with PRP were considered positive regarding the macroscopic evaluation even without statistical difference between groups. In this sense, more consistent results could be obtained with a higher number of samples. In addition, studies that presented significant macroscopic data in favor of PRP were performed 
with chronic wounds, which present low amounts of growth factors due to the decrease in their production or release, sequestration, increased degradation or combination of these factors (STADELMANN et al., 1998; CROVETTI et al., 2004). In the present study, wounds were acute, which may have resulted in the absence of impacting results since in this case the modulation of the inflammatory response was sufficient to favor the adhesion of autografts and the rapid retraction of the wound.

In this study, the microscopic variables related to young fibroblasts, re-epithelialization, inflammatory infiltrate, collagenization, and integration of autografts did not present differences between treated and control groups, which could be explained by the lower platelet concentration than that suggested by VENDRAMIN et al. (2009). Other authors (MONTEIRO et al., 2009) obtained similar results when evaluating the effects of PRP on wound healing in distal limbs of horses since they did not find differences in the inflammatory response and re-epithelialization. In another study (DEROSSI et al., 2009) performed with horses, the effects of PRP gel on the healing of incisional wounds in the neck of these animals were tested and an inflammatory process of greater intensity was observed in the control group. In a study (BAUER et al., 2009) that evaluated the use of PRP in the repair process of standardized dermal wounds in rats, no difference was observed in the population of young fibroblasts and reepithelization. Similarly, another study (PAZZINI \& DE NARDI, 2016) evaluated PRP associated with the surgical sponge in cutaneous grafts in rabbits and also did not observe a difference regarding the polymorphonuclear infiltrate, fibroblastic proliferation, and re-epithelialization.

Conversely, neovascularization was significantly higher on the 14th day after autograft application with PRP. Similar results were reported in studies (KIMURAet al., 2005, KAKUDO et al., 2011) that observed higher neovascularization in the same period. Other studies have also observed a higher vascularization with the use of PRP in the healing of horses, as well as in the healing of cutaneous grafts in rabbits (CARTER et al., 2003, PAZZINI \& DE NARDI, 2016).

In the present study, as in most of the studies described in the available literature, there was no uniformity in the results of the histological analyses, which continues to generate controversies regarding PRP efficacy. Although, this study did not demonstrate statistical difference regarding inflammatory response, re-epithelialization, and presence of young fibroblasts, the animals that received PRP presented a mild inflammatory infiltrate, while the animals in the control group presented a moderate one in D14, as shown in table 2. This result may demonstrate a tendency for the PRP to minimize the inflammatory process during wound healing, which could speed up the completion of the process. Besides that, a significant increase was observed in the neovascularization, which is an important parameter since angiogenesis plays an essential role in the healing process and integration of grafts to the wound bed.

\section{CONCLUSION}

PRP favors the process of skin repair with autografts in equines since it increases neovascularization in the initial phase of wound healing. Moreover, PRP seems to positively influence the integration of skin autografts and the retraction of wound edges, which is essential for reducing the time of hospitalization of the animals and; consequently, the therapeutic costs.

\section{BIOETHICS AND BIOSSECURITY COMMITTEE APPROVAL}

All procedures, treatments and animal care were in compliance with the Ethics Committee on Animal Use of the Federal University of Goiás (CEUA/UFG) (process 074/2016).

\section{DECLARATION OF CONFLICT OF INTEREST}

The authors declare no conflict of interest. The funding sponsors had no role in the design of the study; in the collection, analyses, or interpretation of data; in the writing of the manuscript, and in the decision to publish the results.

\section{ACKNOWLEDGEMENTS}

The authors would like to thank Coordenação de Aperfeiçoamento de Pessoal de Nível Superior (CAPES) for the scholarship granted and for making scientific literature available through the CAPES journal.

\section{AUTHORS' CONTRIBUTIONS}

ACBRP,LRGB and VMBDM conceived and designed the experiment. ESAB carried out the histological analysis. ACBRP, AKLQ and JPCScarried out the experiment and the descriptive analyses. ACBRP, LRGB and VMBDM prepared the draftof the manuscript, approved the final versionand prepared the draft and critically revised the manuscript.

\section{REFERENCES}

BADYLAK, S. F. Xenogeneic extracellular matrix as a scaffold for tissue reconstruction. Transpl. Immunol, v.12, n.3-4, 
p.367-77, 2004. Available from: <https://pubmed.ncbi.nlm. nih.gov/15157928/>. Accessed: Jan. 18, 2021. doi: 10.1016/j. trim.2003.12.016.

BAUER, J. A et al. Efeitos do plasma rico em plaquetas no processo de reparação de feridas dérmicas padronizadas em ratos. Periodontol, v.19, n.3, p.98-108, 2009. Available from: <https:// www.teses.usp.br/teses/disponiveis/23/23146/tde-19122009114243/pt-br.php>.Acessed: jan 18, 2021.

BERTONE, A. L. Management of exuberant granulation tissue. Vet. Clin. North Am. Equine Pract, v.5, n.3, p.551-62, 1989. Available from: <https://pubmed.ncbi.nlm.nih.gov/2691030/>. Accessed: Jan. 18, 2021. doi: 10.1016/s0749-0739(17)30574-6.

BRISTOL, D. G. Skin grafts and skin flaps in the horse. Vet. Clin. North Am. Equine Pract, v.21, n.1, p.125-44, 2005. Available from: <https://pubmed.ncbi.nlm.nih.gov/15691604/>. Accessed: Jan. 18, 2021. doi: 10.1016/j.cveq.2004.11.007.

BONFÁ, A. F et al. Effect of platelet-rich plasma gel on graft skin healing in equines. Ci. Anim. Bras, v.18, p.1-12, 2017. Available from: $\quad<$ http://www.scielo.br/scielo.php?script=sci_arttext\&pid $=$ S0102-86502009000400006 $>$. Accessed: Jan. 18, 2021. doi: $10.1590 / \mathrm{S} 0102-86502009000400006$.

CARTER, C. A et al. Platelet-rich plasma gel promotes differentiation and regeneration during equine wound healing. Exp. Mol. Pathol, v.74, n.3, p.244-55, 2003. Available from: $<$ https://pubmed.ncbi.nlm.nih.gov/12782011/>. Accessed: Jan. 18, 2021. doi: 10.1016/s0014-4800(03)00017-0.

COCHRANE, C. A et al. Effect of growth factors on the characteristics of cells associated with equine wound healing and sarcoid formation. Wound Repair Regen, v.4, n.1, p.58-65, 2017. Available from: < https://pubmed.ncbi.nlm.nih.gov/17129349/>. Accessed: Jan. 18, 2021. doi: 10.1046/j.1524-475X.1996.40111.x.

CROVETTI, G. et al. Platelet gel for healing cutaneous chronic wounds. Transfus. Apher. Sci, v.30, n.2, p.145-51, 2004. Available from: <https://pubmed.ncbi.nlm.nih.gov/15062754/>. Accessed: Jan. 18, 2021. doi: 10.1016/j.transci.2004.01.004.

DAHLGREN, L. Skin grafting. In: ROBINSON, E; SPRAYBERRY, K. Current Therapy in Equine Medicine. 6 ed. St. Louis: Saunders, 2009. Chap 126. p.721-26.

DEROSSI, $\mathrm{R}$ et al. Effects of platelet-rich plasma gel on skin healing in surgical wound in horses. Acta Cir. Bras, v.24, n.4, p.276-81, 2009. Available from: <http://www.scielo.br/scielo. php?script $=$ sci_arttext\&pid $=$ S0102-86502009000400006 $>$. Accessed: Jan. 18, 2021. doi: 10.1590/S0102-86502009000400006.

HEE, HT et al. Do autologous growth factors enhance transforaminal lumbar interbody fusion? Eur. Spine J, v.12, n.4, p.400-7, 2003. Available from: <https://pubmed.ncbi.nlm.nih.gov/12761669/>. Accessed: Jan. 18, 2021. doi: 10.1007/s00586-003-0548-5.

KAKUDO, N. et al. Platelet-rich plasma promotes epithelialization and angiogenesis in a splitthickness skin graft donor site. Med. Mol. Morphol, v.44, n.4, p.233-6, 2011. Available from: <https:// pubmed.ncbi.nlm.nih.gov/22179187/>. Accessed: jan 18, 2021. doi: 10.1007/s00795-010-0532-1.

KIMURA, A. et al. The effects of platelet-rich plasma on cutaneous incisional wound healing in rats. J. Dermatol. Sci, v.40, p.205-8, 2005. Available from: <https://pubmed.ncbi.nlm. nih.gov/16321720/>. Accessed: Jan. 18, 2021. doi: 10.1016/j. jdermsci.2005.07.007.

LANSDOWN, DA; FORTIER, LA. Platelet-Rich Plasma: Formulations, Preparations, Constituents, and Their Effects. Oper. Tech. Sports Med, v.25, n.1, p.7-12, 2017. Available from: <https://www.sciencedirect.com/science/article/abs/pii/ S1060187216300582 >. Accessed: Jan. 18, 2021. doi: 10.1053/j. otsm.2016.12.002.

LEPAULT, É. et al. Comparative study on microvascular occlusion and apoptosis in body and limb wounds in the horse. Wound Repair Regen, v.13, n.5, p.520-9, 2017. Available from: <https:// pubmed.ncbi.nlm.nih.gov/16176461/>. Accessed: Jan. 18, 2021. doi: 10.1111/j.1067-1927.2005.00073.x.

MARX, R. E. Platelet-rich plasma (PRP): what is PRP and what is not PRP? Implant Den, v.10, n.4, p.225-8, 2001. Available: $<$ https://pubmed.ncbi.nlm.nih.gov/11813662/>. Accessed: Jan. 18, 2021. doi: 10.1097/00008505-200110000-00002.

MARX, R. E. Platelet-rich plasma: evidence to support its use. J. Oral Maxillofac. Surg, v.62, n. 4, p.489-96, 2004. Available from: $<$ https://pubmed.ncbi.nlm.nih.gov/15085519/>. Accessed: Jan. 18, 2021. doi: $10.1016 /$ j.joms.2003.12.003.

MONTEIRO, S. O. et al. Effects of platelet-rich plasma on the repair of wounds on the distal aspect of the forelimb in horses. Am. J. Vet. Re, v.70, n.2, p.277-82, 2009. Available from: <https:// pubmed.ncbi.nlm.nih.gov/19231962/>. Accessed: Jan. 18, 2021. doi: 10.2460/ajvr.70.2.277.

PAZZINI, J. M; DE NARDI, A. B. Uso de esponja cirúrgica em enxertos cutâneos associado ao plasma rico em plaquetas em coelhos (Oryctolaguscuniculus). Rev. Bras. Med. Vet, v.38, n.4, p.397-405, 2016. Available from: <https://repositorio.unesp.br/ handle/11449/150128>. Accessed: Jan. 18, 2021.

PIERCE, G. F. et al. Role of platelet-derived growth factor in wound healing.J. Cell Biochem, v.45, n.4, p.319-26, 1991. Available from: <https://pubmed.ncbi.nlm.nih.gov/2045423/>. Accessed: Jan. 18, 2021. doi: 10.1002/jcb.240450403.

SANCHEZ, M. et al. Comparison of surgically repaired Achilles tendon tears using platelet-rich fibrin matrices. Am. J. Sports Med, v.35, n.2, p.245-51, 2007. Available from: <https://pubmed. ncbi.nlm.nih.gov/17099241/>. Accessed: Jan. 18, 2021. doi: $10.1177 / 0363546506294078$.

SCHUMACHER, J; WILMINK, J. Free Skin Grafting. In: SCHUMACHER, J; THEORET, CL.Equine Wound Management. 3 ed. Iowa: John Wiley \& Sons, 2017. Chap. 18. p.422-48.

SCHWARTZ, AJ et al. Factors regulating collagen synthesis and degradation during second-intention healing of wounds in the thoracic region and the distal aspect of the forelimb of horses. Am. J. Vet. Res. v.63, n.1, p.1564-1570, 2005. Available from: <https:// pubmed.ncbi.nlm.nih.gov/12428668/>. Accessed: Jan. 18, 2021. doi: 10.2460/ajvr.2002.63.1564.

STADELMANN, W. K. et al. Physiology and healing dynamics of chronic cutaneous wounds. Am. J. Surg. 176, Suppl, v.2A, p.26-38, 1998. Available from: <https://pubmed.ncbi.nlm.nih. gov/9777970/>. Accessed: Jan. 18, 2021. doi: 10.1016/s00029610(98)00183-4. 
THEORET, C. L. et al. Expression of transforming growth factor beta (1), beta (3), and basic fibroblast growth factor in fullthickness skin wounds of equine limbs and thorax. Vet. Surg, v.30, n.3, p.269-77, 2001. Available from: <https://pubmed.ncbi. nlm.nih.gov/11340559/>. Accessed: Jan. 18, 2021. doi: 10.1053/ jvet.2001.23341.

TZENG, Y. S. et al. Treatment of nonhealing diabetic lower extremity ulcers with skin graft and autologous platelet gel: a case series. BioMed Res, p.1-9, 2013. Available from: <https:// pubmed.ncbi.nlm.nih.gov/23607097/>. Accessed: Jan. 18, 2021. doi:10.1155/2013/837620.

VENDRAMIN, FS et al. Método de obtenção do gel de plasma rico em plaquetas autólogo. Rev. Bras. Cir. Plást, v.24, n.2, p.212-
8, 2009.Availablefrom: <http://www.rbcp.org.br/details/471/ pt-BR/metodo-de-obtencao-do-gel-de-plasma-rico-em-plaquetasautologo>. Accessed: Jan. 18, 2021.

VENDRAMIN, F. S. et al. Use of autologous platelet-rich plasma in skin grafts surgeries in chronic wounds. Rev. Bras. Cir. Plást, v.25, n.4, p.589-94, 2010. Available from: <http://www.rbcp.org. br/details/748/use-of-autologous-platelet-rich-plasma-in-skingrafts-surgeries-in-chronic-wounds>. Accessed: Jan. 18, 2021.

WILMINK, J. M. et al. Differences in second-intention wound healing between horses and ponies: histological aspects. Equine Vet, J. v.31, n.1, p.61-7, 1999. Available from: <https://pubmed. ncbi.nlm.nih.gov/9952331/>. Accessed: Jan. 18, 2021. doi: 10.1111/j.2042-3306.1999.tb03792.x. 